\title{
A CRITICAL ANALYSIS ON THE USE OF THE OPPRESSION REMEDY BY DIRECTORS REMOVED FROM OFFICE BY THE BOARD OF DIRECTORS UNDER THE COMPANIES ACT 71 OF 2008
}

\author{
Rehana Cassim \\ $B A$ (cum laude) LLB (cum laude) LLM (cum laude) \\ LLD \\ Associate Professor, University of South Africa \\ Attorney and Notary Public of the High Court of \\ South Africa
}

\section{SUMMARY}

Both sections 71(3) and 163 of the Companies Act 71 of 2008 are innovative in South African company law in that the former section permits the board of directors to remove a fellow director from office, while the latter section extends the oppression remedy to directors. Previously, under the Companies Act 61 of 1973, the power to remove directors from office was confined to shareholders. Moreover, only shareholders could apply for relief from oppressive or prejudicial conduct. Now that section 163 of the Companies Act 71 of 2008 has been extended to directors, this article argues that a director who has been removed from office by the board of directors under section 71(3) of the Companies Act may rely on the oppression remedy for relief if his or her removal from office was oppressive or unfairly prejudicial or if it unfairly disregarded his or her interests. The article further examines the nature of any orders a court may grant in this context. It argues further that, in the interests of fairness, clarity and certainty, section 163 of the Companies Act 71 of 2008 ought to be amended to make it clear that the section may be relied upon by a former director.

\section{INTRODUCTION}

The Companies Act 71 of 2008 (the Companies Act) introduced into South African company law a provision that for the first time permits, in specific instances, a board of directors to remove a fellow director from office. This provision is contained in section 71(3). Previously, under section 220 of the Companies Act 61 of 1973 (the 1973 Companies Act), the power to remove directors from office was confined to shareholders. Section 163 of the Companies Act is also novel in South African law in that it extends the oppression remedy to directors; unlike the position under section 252 of the 
1973 Companies Act, the remedy is no longer confined for use by shareholders. ${ }^{1}$ The oppression remedy has traditionally served the purpose of protecting oppressed minority shareholders. ${ }^{2}$

Now that section 163 of the Companies Act has been extended to directors, the question arises whether a director who has been removed from office by the board of directors under section 71(3) of the Companies Act may rely on the oppression remedy for relief if his or her removal was oppressive, unfairly prejudicial or unfairly disregarded his or her interests. This article critically analyses this question. It further examines the nature of any orders a court may grant in this context.

Section 5(2) of the Companies Act provides that, to the extent appropriate, a court interpreting or applying the Companies Act may consider foreign company law. It is notable that the corporate legislation of the United Kingdom (UK) and Australia has strongly influenced the Companies Act. Since section 163 of the Companies Act is modelled on and draws from both section 994 of the UK Companies Act of 2006 (UK Companies Act) as well as section 232 of the Australian Corporations Act of 2001 (Australian Corporations Act), this article will, where relevant, refer to these provisions in order to ascertain whether, in interpreting and applying section 163 of the Companies Act, any guidance may be obtained from these jurisdictions.

\section{THE REMOVAL OF DIRECTORS BY THE BOARD OF DIRECTORS}

Section 71(3) of the Companies Act permits the board of directors to remove a director from office in instances where a company has more than two directors, and a shareholder or a director alleges that a director of the company has become ineligible or disqualified to be a director, or has become incapacitated to the extent that the director is unable to perform the functions of a director and is unlikely to regain that capacity within a reasonable time, or has neglected or been derelict in the performance of the functions of a director. The matter is to be determined by a board resolution in which the members of the board, save for the director concerned, must vote on the proposed removal resolution. ${ }^{3}$ If a company has fewer than three directors, the board may not remove a director from office but a director or a shareholder of the company may apply to the Companies Tribunal to make a determination on the removal of a director. ${ }^{4}$

It is trite that a shareholder's right to vote, being a proprietary right of shareholding, may ordinarily be exercised in any way the shareholder pleases. ${ }^{5}$ In sharp contrast, when a board of directors exercises its power to

See Smyth v Investec Bank Ltd [2018] 1 All SA 1 (SCA) par 54 for a comparison between s 252 of the 1973 Companies Act and s 163 of the Companies Act.

Off-Beat Holiday Club v Sanbonani Holiday Spa Shareblock Ltd 2017 (5) SA 9 (CC) par 27.

S 71(3) of the Companies Act.

$\mathrm{S} 71(8)$ of the Companies Act.

Pender v Lushington (1877) 46 ChD 317 321; Re HR Harmer Ltd [1959] 1 WLR 62 82; Sammel v President Brand Gold Mining Co Ltd 1969 (3) SA 629 (A) 680; Desai v Greyridge Investments (Pty) Ltd 1974 (1) SA 509 (A) 519; Kuwait Asia Bank EC v National Mutual Life 
remove a director from office, it must comply with its fiduciary duties to the company. Consequently, if directors vote to remove a director from office under section 71(3) of the Companies Act, they must do so in good faith and for a proper purpose, and in the best interests of the company. ${ }^{6}$ In deciding what is in the best interests of the company, directors have a duty to consider the affairs of the company in an unbiased and objective manner, and to exercise an independent and unfettered discretion. ${ }^{7}$ Consequently, if a director removes a fellow board member under section 71(3) of the Companies Act for an improper purpose or with ulterior motives, such a director will be in breach of his or her fiduciary duties to the company.

\section{THE OPPRESSION REMEDY}

Section 163 of the Companies Act provides a director with a remedy against any oppressive or unfairly prejudicial acts or omissions of a company or conduct that unfairly disregards the interests of that director. On considering the application, a court may make any interim or final order it considers fit. Section 163 provides as follows:

"(1) A shareholder or a director of a company may apply to a court for relief if-

(a) any act or omission of the company, or a related person, has had a result that is oppressive or unfairly prejudicial to, or that unfairly disregards the interests of, the applicant;

(b) the business of the company, or a related person, is being or has been carried on or conducted in a manner that is oppressive or unfairly prejudicial to, or that unfairly disregards the interests of, the applicant; or

(c) the powers of a director or prescribed officer of the company, or a person related to the company, are being or have been exercised in a manner that is oppressive or unfairly prejudicial to, or that unfairly disregards the interests of, the applicant."

Nominees Ltd [1991] 1 AC 187 (PC) 221; CDH Invest NV v Petrotank South Africa (Pty) Ltd [2018] 1 All SA 450 (GJ) par 44.

6 Ss 76(3)(a) and (b) of the Companies Act; Fisheries Development Corporation of SA Ltd v Jorgensen; Fisheries Development Corporation of SA Ltd v AWJ Investments (Pty) Ltd 1980 (4) SA 156 (W) 163; Extrasure Travel Insurances Ltd v Scattergood [2003] 1 BCLC 598 (ChD) 619; Liwszyc v Smolarek (2005) 55 ACSR 38 46; Da Silva v CH Chemicals (Pty) Ltd 2008 (6) SA 620 (SCA) par 18; Visser Sitrus (Pty) Ltd v Goede Hoop Sitrus (Pty) Ltd 2014 (5) SA 179 (WCC) par 80; Eclairs Group Ltd v JKX Oil \& Gas plc [2015] UKSC 71 par 15; Companies and Intellectual Property Commission v Tshelane (99920/2015) [2017] ZAGPPHC 720 (13 November 2017) par 67 and 69; CDH Invest NV v Petrotank South Africa (Pty) Ltd supra par 47.

7 Fisheries Development Corporation of SA Ltd v Jorgensen supra 163; Mthimunye-Bakoro v Petroleum and Oil Corporation of South Africa (SOC) Ltd 2015 (6) SA 338 (WCC) 340.

8 S 163(2) of the Companies Act. A detailed analysis of S 163 of the Companies Act is beyond the scope of this article. For a detailed discussion of this remedy refer to Cassim, Cassim, Cassim, Jooste, Shev and Yeats Contemporary Company Law 2ed (2012) 757775; Delport Henochsberg on the Companies Act 71 of 2008 (Service Issue 18 2018) (2011) 574(1)-574(23) and Cassim The New Derivative Action under the Companies Act: Guidelines for Judicial Discretion (2016) 179-217. 
An "act or omission of the company" encompasses the resolutions of the board of directors and the acts of the board of directors. ${ }^{9}$ In Visser Sitrus (Pty) Ltd $v$ Goede Hoop Sitrus (Pty) Ltd, ${ }^{10}$ the court observed that in most cases the exercise by a director of a corporate power will also be an act of the company. An "act or omission of the company" may also comprise an act or omission of the directors that is done in breach of a duty owed to the company. In Civils 2000 Holdings (Pty) Ltd v Black Empowerment Partner Civils 2000 (Pty) $L t d,{ }^{11}$ the court affirmed that the breach of a fiduciary duty on the part of the directors amounted to conduct of a company as contemplated in section 252 of the 1973 Companies Act.

\section{The meaning of the terms "oppressive", "unfairly prejudicial" and "unfairly disregards"}

The terms "oppressive", "unfairly prejudicial" and "unfairly disregards" in respect of the interests of an applicant shareholder or director are openended terms that have not been defined in the Companies Act. The common-law jurisprudence relating to section 252 of the 1973 Companies Act is instructive in determining whether conduct is oppressive or unfairly prejudicial, given the similarity in wording between that section and section 163 of the Companies Act. ${ }^{12}$ In Grancy Property Ltd $v$ Manala, ${ }^{13}$ the Supreme Court of Appeal commented that, following the approach adopted under section 252 of the 1973 Companies Act, the terms "oppressive", "unfairly prejudicial" and "unfairly disregards" must be construed in a manner that will advance, rather than limit, the remedy. ${ }^{14}$ This approach is consistent with the purposes of the Companies Act, which include the balancing the rights and obligations of shareholders and directors within the company, and encouraging the efficient and responsible management of companies. ${ }^{15}$

The essential test of the oppression remedy is unfairness, not unlawfulness. ${ }^{16}$ The term "oppressive" has been defined as involving a lack

9 Civils 2000 Holdings (Pty) Ltd v Black Empowerment Partner Civils 2000 (Pty) Ltd [2011] 3 All SA 215 (CC) par 17-21.

10 Supra par 53.

11 Supra par 21.

12 Peel v Hamon J \& C Engineering (Pty) Ltd 2013 (2) SA 331 (GSJ) par 43; Grancy Property Ltd $v$ Manala 2015 (3) SA 313 (SCA) par 22; Omar $v$ Inhouse Venue Technical Management (Pty) Ltd 2015 (3) SA 146 (WCC) par 4; Geffen v Martin [2018] 1 All SA 21 (WCC) par 23. For a detailed discussion on the meaning of these terms, see Cassim et al Contemporary Company Law 769-772; Delport Henochsberg on the Companies Act 71 of 2008 574(5)-574(16) and Cassim The New Derivative Action under the Companies Act: Guidelines for Judicial Discretion 190-199.

13 Supra par 26.

14 See further Kudumane Investment Holding Ltd v Northern Cape Manganese Company (Pty) Ltd [2012] 4 All SA 203 (GSJ) par 60; Smyth v Investec Bank Ltd 2016 (4) SA 363 (GP) par 49; Off-Beat Club v Sanbonani Holiday Spa Shareblock Ltd supra par 27; Engelbrecht v Coleman 2017 JDR 0415 (GJ) par 5 and Smyth v Investec Bank Ltd [2018] 1 All SA 1 (SCA) par 20.

15 S 7 of the Companies Act; Harilal v Rajman [2017] 2 All SA 188 (KZD) par 86.

16 Donaldson Investments (Pty) Ltd $v$ Anglo-Transvaal Collieries Ltd: SA Mutual Life Assurance Society 1979 (3) SA 713 (W) 722; Visser Sitrus (Pty) Ltd v Goede Hoop Sitrus (Pty) Ltd supra par 57-59; Off-Beat Holiday Club v Sanbonani Holiday Spa Shareblock Ltd 
of probity and fair dealing in the affairs of the company. ${ }^{17}$ In Visser Sitrus (Pty) Ltd $v$ Goede Hoop Sitrus (Pty) $L t d,{ }^{18}$ the court observed that the term "oppressive" appears to cover conduct of a more egregious kind than conduct that is "unfairly prejudicial to" or that "unfairly disregards the interests of" the applicant. ${ }^{19}$ Mere prejudice is not sufficient to succeed under section 163 of the Companies Act; the conduct must be "unfairly" prejudicial, or must "unfairly" disregard the interests of the applicant. ${ }^{20}$ It must be conduct that departs from the accepted standards of fair play. ${ }^{21}$ "Fairness" is an "elastic" concept and depends on the context in which the word is being used. ${ }^{22}$

In order to rely successfully on section 163 of the Companies Act, it is not necessary for a director to prove that the board of directors acted with an underlying dishonest or ulterior motive in removing him or her from office, since it is the conduct itself and its effect that is relevant. However, motive is indeed relevant in considering whether the conduct complained of reveals a lack of probity and fair dealing and is unfair. ${ }^{23}$ Consequently, the underlying motive of the board of directors in removing a fellow director from office would be of assistance to a court in determining whether the act or the exercise of the power is oppressive, unfairly prejudicial or unfairly disregards the director's interests in the context of section 163(1) of the Companies Act.

\section{The "interests" of the applicant}

Under section 163(1) of the Companies Act, the oppression remedy may be relied on if the powers of a director have been exercised so as to unfairly

supra par 28; De Sousa v Technology Corporate Management (Proprietary) Limited 2017 (5) SA 577 (GJ) par 36.

17 Scottish Co-operative Wholesale Society Ltd v Meyer [1958] 3 All ER 66 (HL) 86; Aspek Pipe Co (Pty) Ltd v Mauerberger 1968 (1) SA 517 (C) 526; Donaldson Investments (Pty) Ltd $\checkmark$ Anglo-Transvaal Collieries Ltd supra 722; Omar v Inhouse Venue Technical Management (Pty) Ltd supra par 9; Grancy Property Ltd v Manala supra par 23; De Sousa v Technology Corporate Management (Proprietary) Limited supra par 40; Harilal v Rajman supra par 85.

18 Supra par 54

19 The terms "oppressive", "unfairly prejudicial" and "unfairly disregards" may be construed as distinct alternatives in respect of the interests of the applicant, but may also be read as a compound expression directed at conduct that is unjustly detrimental to the interests of the applicant or conduct that is commercially unfair (Cassim The New Derivative Action under the Companies Act: Guidelines for Judicial Discretion 190-191). In Count Gotthard SA Pilati $v$ Witfontein Game Farm (Pty) Ltd [2013] 2 All SA 190 (GNP) par 17.12, the court held that it was not necessary in the context of that case to decide whether the phrases in $s$ 163(1) of the Companies Act must be read as a composite whole or not, but that the interests that are unfairly prejudicial must result in commercial unfairness affecting the applicant in such capacity. Australian law adopts the view that the words are to be viewed as a compound expression (see Fexuto Pty Limited v Bosnjak Holdings Pty Limited Matter No 3799/97 [1998] NSWSC 413 (9 September 1998)).

20 Visser Sitrus (Pty) Ltd v Goede Hoop Sitrus (Pty) Ltd supra par 55; Geffen v Martin supra par 25 and 29.

21 Aspek Pipe Co (Pty) Ltd v Mauerberger supra 527-528; Donaldson Investments (Pty) Ltd v Anglo-Transvaal Collieries Ltd supra 722.

22 De Sousa $v$ Technology Corporate Management (Proprietary) Limited supra par 36.

23 Aspek Pipe Co (Pty) Ltd v Mauerberger supra 529; Donaldson Investments (Pty) Ltd v Anglo-Transvaal Collieries Ltd supra 720-721; Ben-Tovim v Ben-Tovim 2001 (3) SA 1074 (C) 1091; Grancy Property Ltd v Manala supra par 27. 
disregard the interests of the applicant (author's own emphasis). The term "interests" is not defined in the Companies Act. It is a wider concept than "rights" ${ }^{24}$ and its inclusion in section 163 of the Companies Act highlights the principle that the oppression remedy is not limited to a strict case of infringement of legal rights but also extends to the protection of the interests of the applicant. ${ }^{25}$ "Interests" may include wider equitable considerations, such as the petitioner's legitimate expectations that go beyond his or her legal rights. ${ }^{26}$

Legitimate expectations emanate from a mutual understanding or agreement that forms the basis on which a company's affairs are conducted, even though these expectations are not necessarily incorporated in the constitution of the company. ${ }^{27}$ One example of a legitimate expectation is the assumption that each party who has ventured his or her capital will also participate in the management of the company and receive a return on the investment in the form of a salary rather than a dividend. ${ }^{28}$ In Count Gotthard SA Pilati $v$ Witfontein Game Farm (Pty) Ltd, ${ }^{29}$ the court found that the concept of "interests" included interests not flowing from the Memorandum of Incorporation of the company but from an understanding or agreement between the parties. The court stated that the acts complained of consequently need not necessarily flow from the Companies Act or the Memorandum of Incorporation; they could arise from a breach of trust or some acrimony between the parties flowing from the fundamental understanding between them. ${ }^{30}$

In many instances in a quasi-partnership ${ }^{31}$ (where the shareholders are also directors), a shareholder who has ventured his or her capital in the

24 Kudumane Investment Holding Ltd v Northern Cape Manganese Company (Pty) Ltd supra par 58; Count Gotthard SA Pilati v Witfontein Game Farm (Pty) Ltd supra par 15 and 17.2; Grancy Property Ltd v Manala supra par 26; Smyth v Investec Bank Ltd 2016 (4) SA 363 (GP) par 45. For a further discussion of the term "interests", see Delport Henochsberg on the Companies Act 71 of 2008 574(16)-574(17) and Cassim The New Derivative Action under the Companies Act: Guidelines for Judicial Discretion 192.

25 Grancy Property Ltd v Manala supra par 26.

26 Re Ringtower Holdings plc (1989) 5 BCC 82 90; Re Saul D Harrison \& Sons plc [1995] 1 BCLC 14 (CA) 31. For a further discussion of the concept of legitimate expectations in the context of the oppression remedy, see Austin and Ramsay Ford, Austin and Ramsay's Principles of Corporations Law 16ed (2015) 749-750; Davies and Worthington Gower Principles of Modern Company Law 10ed (2016) 665-670.

Re Ringtower Holdings plc supra 90; Re Saul D Harrison \& Sons plc supra 19.

28 Re Saul D Harrison \& Sons plc supra 19.

29 Supra par 17.4.

30 lbid.

31 A quasi-partnership usually involves a small private company that in effect runs as a partnership between the shareholders. The shareholders agree to go into a business venture together on the basis of an agreement or understanding that all the shareholders will participate in the management of the company's business and that they will all be appointed as directors of the company. Voluntary exit of a quasi-partnership by a disgruntled minority shareholder is difficult because of the challenges associated with selling a minority stake in a private company, and the restricted transferability of the shares of a private company. It is not required that the company be run as if it were a partnership or that the shareholders regard themselves as being partners (see Ebrahimi $v$ Westbourne Galleries Ltd [1972] 2 All ER 492 (HL) 500; Barnard v Carl Greaves Brokers (Pty) Ltd 2008 (3) SA 663 (C) par 11; Croly v Good [2010] EWHC 1 (Ch) par 9 and 89-93; De Sousa v Technology Corporate Management (Proprietary) Limited supra par 47. 
company's business has a legitimate expectation that he or she will continue to be appointed as a director. Removal as a director and exclusion from the management of the company in such circumstances is accordingly regarded as being unfairly prejudicial to the shareholder's interests. ${ }^{32}$ In English law, it is well established that the removal of a director in a quasi-partnership may amount to unfairly prejudicial conduct in the absence of a fair offer by the majority to purchase the director's shares or some other fair arrangement. ${ }^{33}$ Section 994(1) of the UK Companies Act restricts the unfair prejudice remedy to shareholders of the company. ${ }^{34}$ Consequently, in order to claim unfair prejudice, a director who has been removed from office must be a shareholder of the company or must be a person to whom shares have been transferred or transmitted.

In cases of quasi-partnership, courts are generally more willing to find that a director removed from office and thus excluded from the management of the company has been subjected to unfairly prejudicial treatment in his capacity as a shareholder. ${ }^{36}$ For example, in In Re I Fit Global Ltd, ${ }^{37}$ the petitioner and the respondent had agreed on the basis of a partnership understanding to establish a company with each holding an equal shareholding. The petitioner was dismissed as a director 19 months after the company had been incorporated and was consequently excluded from the management of the company. The Chancery Division found that, given the basis on which the company had been established, the exclusion of the petitioner as a director of the company was clearly unfair and prejudicial to his interests as a shareholder under section 994 of the UK Companies Act. ${ }^{38}$

The mere fact that a company is a quasi-partnership is not necessarily sufficient to raise a legitimate expectation that each partner will take part in the management of the company. ${ }^{39}$ The legitimate expectation that each partner would take part in the management of the company is usually derived from the constitution of the company or from the agreement between the parties, but the relationship between the parties may also give rise to a legitimate expectation to participate in the company's management. ${ }^{40} \mathrm{An}$

32 Re a Company (No 00477 of 1986) [1986] BCLC 376 379; O'Neill v Phillips [1999] 1 WLR 1092 par 6; In Re I Fit Global Ltd 2013 WL 3550422 par 46.

33 O'Neill $v$ Phillips supra par 6.

34 S 994(1) of the UK Companies Act states as follows:

"A member of a company may apply to the court by petition for an order under this Part on the ground-

(a) that the company's affairs are being or have been conducted in a manner that is unfairly prejudicial to the interests of members generally or of some part of its members (including at least himself),

(b) that an actual or proposed act or omission of the company (including an act or omission on its behalf) is or would be so prejudicial."

35 See s 994(2) of the UK Companies Act.

36 Re Bird Precision Bellows Ltd [1985] 3 All ER 523; Re London School of Electronics [1986] 1 Ch 211.

37 Supra.

38 Par 47.

39 Ebrahimi v Westbourne Galleries Ltd supra 500; Re Ringtower Holdings plc supra 93.

40 Erasmus v Pentamed Investments (Pty) Ltd 1982 (1) SA 178 (W) 182; De Sousa v Technology Corporate Management (Proprietary) Limited supra par 47. 
aggrieved party must prove his or her legitimate expectation as a fact. ${ }^{41}$ This makes it difficult to establish a legitimate expectation in larger companies that are not run as quasi-partnerships. ${ }^{42}$

A position similar to the UK has been adopted in Australia under the Australian Corporations Act, where the exclusion of a director from management has been held to be oppressive in circumstances where there was a legitimate expectation of participation in management. ${ }^{43}$ Section 232 of the Australian Corporations Act provides for a remedy where the conduct of a company's affairs or an actual or proposed act or omission by or on behalf of the company, or a resolution, or a proposed resolution, of members or a class of members of a company is oppressive or unfairly prejudicial to a member of the company. Like section 994 of the UK Companies Act, section 234 of the Australian Corporations Act confers locus standi on members to apply for relief from oppressive conduct but the provision does not extend to directors as such. However, section 232(e) of the Australian Corporations Act provides relief where conduct is oppressive to, unfairly prejudicial to or unfairly discriminatory against "a member or members whether in that capacity or in any other capacity". Consequently, the application may be brought by a member if it relates to an act or omission against the member in a capacity other than member. It follows that a member may seek relief for oppressive conduct that has an effect on his or her capacity as a director. ${ }^{44}$ It is submitted that this puts it beyond doubt that conduct that unfairly removes a member from a directorship could attract relief under section 232 of the Australian Corporations Act on the basis that it is oppressive or unfairly prejudicial to a member in his or her capacity as a director.

\section{Evaluation}

To apply the above legal principles to the removal of a director from office by the board of directors in South African law, a director who has been removed from office by the board may rely on section 163(1)(a) of the Companies Act on the basis that an act or omission of the company (that is, the board of directors) has had a result (that is, his or her removal from office) that is oppressive or unfairly prejudicial. A director may also rely on section 163(1)(c) of the Companies Act to contend that the powers of a director or directors were exercised in a manner that is oppressive or unfairly prejudicial to him or her. If, however, the removal of a director from office is validly based on one of the specific grounds set out in section 71(3) of the Companies Act, the director would be unable to rely successfully on section

41 Visser Sitrus (Pty) Ltd v Goede Hoop Sitrus (Pty) Ltd supra par 62; Re Ringtower Holdings plc supra 93.

42 Visser Sitrus (Pty) Ltd v Goede Hoop Sitrus (Pty) Ltd supra par 62; Re Blue Arrow plc (1987) 3 BCC 618.

43 See for instance, Hogg $v$ Dymock (1993) 11 ACSR 14 and Yazbek $v$ Aldora Holdings Pty Ltd [2003] NSWSC 330. See further Austin and Ramsay Principles of Corporations Law 756-757 on the improper exclusion from participation in management constituting oppressive or unfairly prejudicial conduct in Australian law.

44 Austin and Ramsay Principles of Corporations Law 761-62. See further Austin and Ramsay Principles of Corporations Law 761-762 for a discussion of the other capacities that may be applicable in this context, such as employee or creditor. 
163 of the Companies Act since his or her removal would not be unfair. However, since a breach of a fiduciary duty may amount to conduct that is oppressive or unfairly prejudicial, if the board removed a director from office in breach of its fiduciary duty, the director could in that event apply to court for relief under section 163 of the Companies Act. While it is not necessary for the director to prove that the board of directors acted with an underlying dishonest or ulterior motive in removing him or her from office, the motive of the board of directors in effecting the removal would be of assistance to a court in deciding whether the act or the exercise of the power was oppressive or unfairly prejudicial.

A director who has been removed from office by the board may, in addition, argue that such removal unfairly disregarded his or her interests. Under the Companies Act, a director of a quasi-partnership has not one, but two, grounds on which he or she may rely in order to use the oppression remedy. The first ground is that in his or her capacity as a shareholder of the quasi-partnership, he or she may contend that an act of the majority shareholders in removing him or her from office unfairly disregards his or her interests, or his or her legitimate expectation as a shareholder to participate in the management of the company, and that neither a fair offer nor some other fair arrangement was made to purchase his or her shares. The second ground is that as a director of the quasi-partnership, he or she may contend that the powers of the board of directors in removing him or her from office were exercised in a manner that was oppressive or unfairly prejudicial to, or that unfairly disregards, his or her interests.

Unlike the position under section 994 of the UK Companies Act or section 232 of the Australian Corporations Act, a director instituting an action under section 163 of the Companies Act with regard to removal from office need not prove that the company is a quasi-partnership nor that he or she had a legitimate expectation not to be removed from office. Since section 163(1)(c) of the Companies Act confers locus standi on a director to base a remedy on oppression, he or she may rely on section 163 of the Companies Act if able to establish that the removal from office by the board of directors was in circumstances that were oppressive or unfairly prejudicial or unfairly disregarded his or her interests. In light of the fact that section 71(3) confers a power on the board of directors to remove a fellow director from office, in order successfully to institute an action under section 163 of the Companies Act, a director removed from office must prove that the removal from office was oppressive or unfairly prejudicial or unfairly disregarded his or her interests. He or she may not rely on vague or general allegations, but bears the onus of proving that the removal from office by the board was oppressive, unfairly prejudicial or unfairly disregarded his or her interests. ${ }^{45}$

45 Aspek Pipe Co (Pty) Ltd v Mauerberger supra 525; Louw v Nel 2011 (2) SA 172 (SCA) par [23]; De Sousa v Technology Corporate Management (Proprietary) Limited supra par 38. 


\section{RELIEF THAT MAY BE GRANTED BY A COURT TO A DIRECTOR REMOVED FROM OFFICE BY THE BOARD OF DIRECTORS}

In considering an application by a director under section 163(1) of the Companies Act, a court may make any interim or final order it considers fit. ${ }^{46}$ In terms of section 163(2) of the Companies Act, wide powers and a discretion to make an appropriate order are conferred on a court. ${ }^{47}$ Section $163(2)(a)-(\Lambda$ lists a wide variety of orders a court may make, but this list is not closed. ${ }^{48}$ In making an order under section 163 of the Companies Act, a court must consider the whole range of possible remedies; it is not limited to putting right the immediate conduct that justifies the order. ${ }^{49} \mathrm{~A}$ court must also look to put right and remedy for the future the unfair prejudice suffered by the petitioner and the likelihood of a recurrence of the conduct. ${ }^{50} \mathrm{~A}$ director who applies for relief in terms of section 163 of the Companies Act should indicate the nature of the relief that he or she seeks. ${ }^{51}$ Nevertheless, even if he or she does not do so, or does not include a particular remedy, section 163(2) empowers a court to make "any interim or final order it considers fit". Some orders that a court may grant in this context, as well as orders that would not be appropriate, are discussed below.

S 163(2) of the Companies Act.

47 Kudumane Investment Holding Ltd v Northern Cape Manganese Company (Pty) Ltd supra par 61; Count Gotthard SA Pilati v Witfontein Game Farm (Pty) Ltd supra par 25.1; Omar v Inhouse Venue Technical Management (Pty) Ltd supra par 50; Off-Beat Holiday Club v Sanbonani Holiday Spa Shareblock Ltd supra par 28; Klerk v Ferreira 2017 (3) SA 502 (GP) par 16.

48 This is made clear by the use of the word "including" in s 163(2) of the Companies Act, which indicates that the court is not limited to the remedies listed in $s$ 163(2) of the Companies Act. See further Grancy Property Ltd v Manala supra par 31, where the Supreme Court of Appeal affirmed that the orders listed under s 163(2) of the Companies Act are non-exhaustive and open-ended. The orders listed in s 163(2) of the Companies Act are: (i) an order restraining the conduct complained of; (ii) an order appointing a liquidator, if the company appears to be insolvent; (iii) an order placing the company under supervision and commencing business rescue proceedings if the court is satisfied that the company is financially distressed and the other circumstances set out in $\mathrm{s} 131(4)(a)$ of the Companies Act apply; (iv) an order to regulate the company's affairs by directing it to amend its Memorandum of Incorporation or to create or amend a unanimous shareholder agreement; (v) an order directing an issue or exchange of shares; (vi) an order appointing directors in place of or in addition to all or any of the directors then in office, or declaring a director to be delinquent or placing a director under probation; (vii) an order directing the company or any other person to restore to a shareholder any part of the consideration that the shareholder paid for shares, or pay the equivalent value, with or without conditions; (viii) an order varying or setting aside a transaction or an agreement to which the company is a party and compensating the company or any other party to the transaction or agreement; (ix) an order requiring the company, within a time specified by the court, to produce to the court or an interested person financial statements in a form required by the Companies Act, or an accounting in any other form the court may determine; $(x)$ an order to pay compensation to an aggrieved person, subject to any other law entitling that person to compensation; (xi) an order directing rectification of the registers or other records of the company; and (xii) an order for the trial of any issue as determined by the court. See Re Bird Precision Bellows Ltd supra 529.

50 Ibid.

51 Lourenco v Ferela (Pty) Ltd (No 1) 1998 (3) SA 281 (T) 295; Louw v Nel supra par 23. 


\section{Compensation}

Under section $163(2)(j)$ of the Companies Act, a court may order compensation to be paid to an aggrieved person, subject to any other law entitling that person to compensation. Consequently, if the conduct of the board of directors in removing a director from office was oppressive or unfairly prejudicial or unfairly disregarded his or her interests, he or she may request the court, in terms of section $163(2)(J)$ of the Companies Act, to order compensation to be paid.

In light of the fact that the compensation order is subject to any other law entitling the person to compensation, it is important to bear in mind the provisions of section 71(9) of the Companies Act. Section 71(9) confers on a director who is removed from office under section 71 of the Companies Act a right to apply to court for damages or other compensation for loss of office as a director or for loss of any other office as a consequence of being removed as a director.

For a director to have a remedy under section 71(9) of the Companies Act, the removal from office must constitute a breach of contract on the part of the company. ${ }^{52}$ A director must have a contract with the company or it must be stated in the Memorandum of Incorporation of the company that the company will not for a specified period of time terminate his or her office of directorship, or any other appointment terminating with the termination of his office as a director. Thus, where a company has appointed a director for a fixed period in terms of a contract or in terms of the Memorandum of Incorporation and that period has not expired at the time the director is removed from office, the affected director is entitled to claim damages or other compensation from the company for a breach of that contract by the company. ${ }^{53}$ The director's contract with the company or the Memorandum of Incorporation may also provide that the director will be entitled to a contractual termination payment upon termination of his or her service contract, in which event the director would be entitled to such agreed compensation upon removal from office. ${ }^{54}$

In order to sustain an action for damages or compensation against a company for loss of office as director, the director must not have breached the Memorandum of Incorporation or the contract of service such that he or she has given cause to the company to cancel the contract. ${ }^{55}$ In the event of such a breach by a director, he or she would not be entitled to damages or compensation for loss of office under section 71(9) of the Companies Act ${ }^{56}$ but may still be entitled to compensation under section 163(2) of the Companies Act.

52 See Davies and Worthington Gower Principles of Modern Company Law 382-383.

53 Southern Foundries (1926) Ltd $v$ Shirlaw [1940] AC 701; Read $v$ Astoria Garage (Streatham) Ltd [1952] 2 All ER 292; De Villiers v Jacobsdal Saltworks (Michaelis \& De Villiers) (Pty) Ltd 1959 (3) SA 873 (O); Davies and Worthington Gower Principles of Modern Company Law 382-383.

54 Davies and Worthington Gower Principles of Modern Company Law 382-383.

55 Farmers' Associated Dairies Ltd v Goldstein 1924 WLD 181183.

56 Knopp $v$ Thane Investments Ltd, Knopp v Tomlinson [2003] 1 BCLC 380 par 131; Item Software (UK) Ltd v Fasshihi [2003] 2 BCLC 1 par 97. 


\section{Reinstatement}

If a court finds that the removal of a director by the board of directors was oppressive, unfairly prejudicial or unfairly disregarded the director's interests, a further order it may make is one reinstating the director to the board. It is submitted that such an order should be made only if it would be appropriate in the circumstances - for instance, if the relationship of the director with the board has not irretrievably broken down.

\section{Restraining order}

Under section 163(2)(a) of the Companies Act, a court may make an order restraining oppressive conduct. It is submitted that a director would probably not be able to obtain a court order to restrain the board from passing a board resolution to remove him or her from office, even if the resolution would constitute oppressive or unfairly prejudicial conduct or would unfairly disregard his or her interests. A director who is the subject of a board resolution to remove him or her from office must be given a reasonable opportunity, in terms of section 71(4)(b) of the Companies Act, to make a presentation to the board of directors, in person or through a representative, before the resolution is put to a vote. In his or her presentation, a director may be able to persuade the board to vote against his or her removal from office. Therefore, a court order in terms of section 163(2)(a) of the Companies Act restraining the board of directors from voting on the proposed resolution would be inappropriate and premature.

Under section 163(1)(a) of the Companies Act, the act or omission of the company must have "had a result" that is oppressive or unfairly prejudicial or that unfairly disregards the interests of the applicant. As the court in Count Gotthard SA Pilati $v$ Witfontein Game Farm (Pty) $L t d^{57}$ emphasised, the phrase "has had a result" in section 163(1)(a) of the Companies Act indicates that the act must be completed and that it is the result, and not the act, that must be oppressive or unfairly prejudicial. This was further affirmed in Kudumane Investment Holding Ltd $v$ Northern Cape Manganese Company (Pty) Ltd, ${ }^{58}$ where the High Court found that the act under section 163 of the Companies Act must be something that had already been done or performed at the time of the application, but not an act that may or will occur only in the future. This buttresses the argument that a director would have to apply for relief under section 163 of the Companies Act only after the board of directors has removed him or her from office in a manner that was oppressive, unfairly prejudicial or that unfairly disregarded his or her interests.

In Porteus $v$ Kelly, ${ }^{59}$ the court held that the mere calling of a meeting to pass a resolution to amend the articles of association of a private company was not in itself unfairly prejudicial on the ground that it related to threatened conduct. The court commented that section 252 of the 1973 Companies Act

\footnotetext{
Supra par 17.6.

58 Supra par 52. See further Pakade NO v Lukhanji Leisure (Pty) Ltd (3390/2016) [2017] ZAECGHC 22 (7 March 2017) par 28.

591975 (1) SA 219 (W). This case dealt with s 252 of the 1973 Companies Act.
} 
did not empower a court to interfere by preventing a resolution from being passed - the provision only related to something that had been done or performed. ${ }^{60}$ It was argued by counsel for the applicant that if a court could interfere after a resolution has been passed, there is no reason in principle why it could not interfere to prevent the resolution from being passed. The court conceded that while it may well be that prevention of an act would be better than curing it after it has been committed, the section does not provide therefor, and that this may be a casus omissus. ${ }^{61}$ In sharp contrast, section 994(1)(b) of the UK Companies Act refers to an "actual or proposed" act or omission of the company that "is or would be so prejudicial". Under this approach, it would not be necessary for the harm to be inflicted. Notably, section 232(c) of the Australian Corporations Act likewise refers to a "resolution, or a proposed resolution" being oppressive or unfairly prejudicial. There is much merit in this approach as it does not require the applicant to wait for the harm to happen before instituting an application for relief. ${ }^{62}$

\section{Declaration of delinquency or probation}

In terms of section 163(2)(f)(ii) of the Companies Act, if a director has acted in an oppressive manner, there is a further possible court order - to declare a person delinquent or under probation, as contemplated in section 162 of the Companies Act. The effect of an order of delinquency is that a person is disqualified from being a director of a company. ${ }^{63}$ A delinquency order may be unconditional and may subsist for the director's lifetime, or, it may be conditional and subsist for seven years or longer, as determined by the court. $^{64}$ The effect of a probation order is that a person may not serve as a director except to the extent permitted by the order. ${ }^{65} \mathrm{~A}$ probation order generally subsists for a period not exceeding five years, ${ }^{66}$ and may be subject to such conditions as the court considers appropriate. ${ }^{67}$ Consequently, if a director votes to remove a fellow director in a manner that is oppressive or unfairly prejudicial to that director or that unfairly disregards his or her interests, he or she may be declared by a court to be delinquent or placed under probation.

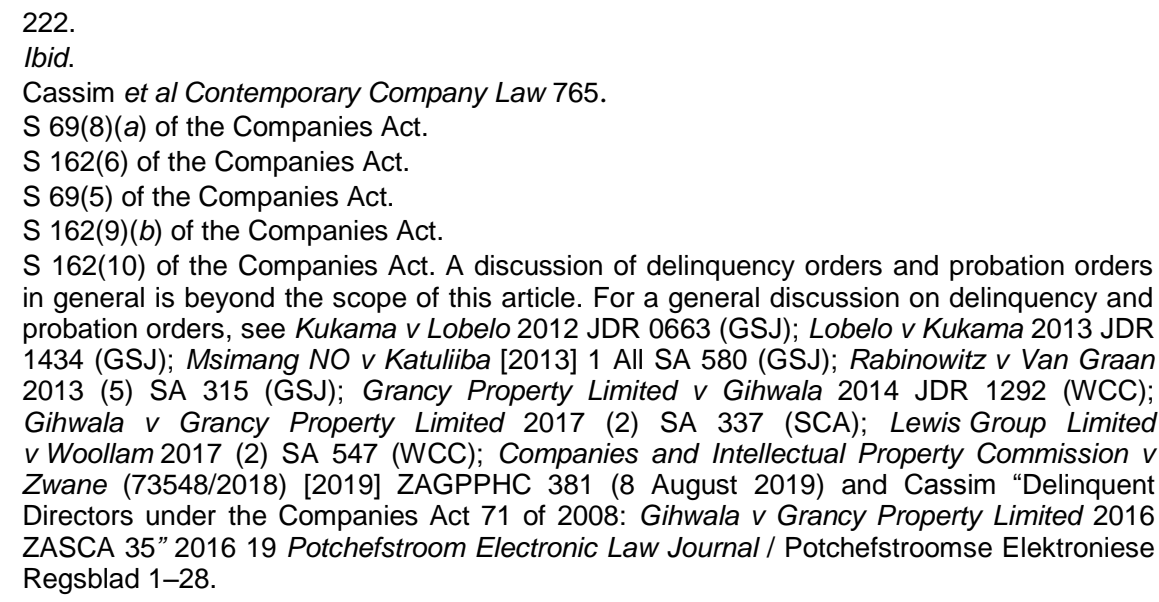
in general is beyond the scope of this article. For a general discussion on delinquency and probation orders, see Kukama v Lobelo 2012 JDR 0663 (GSJ); Lobelo v Kukama 2013 JDR 1434 (GSJ); Msimang NO v Katuliiba [2013] 1 All SA 580 (GSJ); Rabinowitz v Van Graan 2013 (5) SA 315 (GSJ); Grancy Property Limited v Gihwala 2014 JDR 1292 (WCC); Gihwala v Grancy Property Limited 2017 (2) SA 337 (SCA); Lewis Group Limited v Woollam 2017 (2) SA 547 (WCC); Companies and Intellectual Property Commission v Zwane (73548/2018) [2019] ZAGPPHC 381 (8 August 2019) and Cassim "Delinquent Directors under the Companies Act 71 of 2008: Gihwala v Grancy Property Limited 2016 ZASCA 35" 201619 Potchefstroom Electronic Law Journal / Potchefstroomse Elektroniese Regsblad 1-28. 
The placing of a director under probation in terms of section 163(2)(f)(ii) of the Companies Act for acting in an oppressive manner is reinforced by section 162(7)(a)(iii) of the Companies Act. The latter provision states that a court may place a person under probation if, while serving as a director, the person acted in (or supported a decision of the company to act in) a manner contemplated in section 163(1) of the Companies Act. A court may place a person under probation on this ground only if it is satisfied that the declaration is justified having regard to the circumstances of the company's conduct, if applicable, and the person's conduct in relation to the management, business or property of the company at the time. ${ }^{68}$ In other words, the company's conduct and the conduct of the particular oppressor are examined by a court in exercising its discretion ${ }^{69}$ under section 162(7)(a)(iii) as to whether to place a director under probation.

In contrast, section 162(5) of the Companies Act, which sets out the grounds on which a director may be declared delinquent, does not list, as a ground, acting in an oppressive manner as contemplated in section 163(1) of the Companies Act. It appears from section 163(2)(f)(ii) that acting in an oppressive manner as contemplated in section 163(1) is an additional ground on which a director may be declared delinquent. However, this ground of delinquency may not be relied upon by the persons having locus standi under section 162 of the Companies Act since the ground is not listed in section 162(5). It may only be relied upon by a court in making an order under section 163(2) of the Companies Act when a director has been found to have acted in an oppressive manner. It is submitted that this is a proper approach. While a court has a discretion whether or not to put a director under probation, it does not have a discretion whether or not to declare a director delinquent if any of the grounds set out in section 162(5) are established. ${ }^{70}$ If this ground were to be listed in section 162(5), a court would be obliged to declare delinquent a director who had acted in an oppressive manner. Such an order could, in certain circumstances, be too harsh. Under the current regulation, a court has a discretion under section 163(2)(f)(ii) whether or not to declare a director delinquent if he or she had acted in an oppressive manner.

\section{APPLICATION OF THE OPPRESSION REMEDY TO FORMER DIRECTORS}

Section 163(1) of the Companies Act confers locus standi to apply to court for relief on a "director", but not on a "former director". As discussed above, a director may apply for relief under section 163 of the Companies Act only after the board of directors has removed him or her from office in a manner that was oppressive, unfairly prejudicial or unfairly disregarded his or her interests, and not when such removal is only anticipated. This raises the question whether a director who has been removed from office by the board

68 S 162(8)(a) of the Companies Act.

69 S 162(7) of the Companies Act gives a court a discretion whether or not to place a person under probation.

70 See s 162(5) of the Companies Act, which obliges a court to declare a person a delinquent director if any of the grounds set out in that section are established. 
of directors, or by the Companies Tribunal, in a manner that was oppressive, unfairly prejudicial or unfairly disregarded his or her interests, and is consequently no longer a "director" of the company, would in fact have locus standi to institute an application for relief under section 163 of the Companies Act, or whether he or she would now lack standing to do so.

It is noteworthy that section 234 of the Australian Corporations Act, which sets out the persons who have locus standi to apply to court for relief from oppressive conduct, explicitly makes provision for a former member to apply to court for relief where a person has ceased to be a member of the company and where the application relates to the circumstances in which such person ceased to be a member ${ }^{71}$ In a similar vein, it is submitted that, in the interests of fairness, clarity and certainty, section 163 of the Companies Act should be amended to state that the provision may be relied on by a person who has been removed from office by the board of directors (in terms of section 71(3) of the Companies Act) or the Companies Tribunal (in terms of section 71(8) of the Companies Act) if the application relates to the circumstances in which he or she was removed from office. Such an amendment would remove any doubt that former directors, who have been removed from office by the board of directors or the Companies Tribunal in a manner that was oppressive, unfairly prejudicial or that unfairly disregarded their interests, are entitled to apply to court for relief under section 163 of the Companies Act.

\section{CONCLUSION}

It was argued in this article that a director who has been removed from office by the board of directors under section 71(3) of the Companies Act may rely on the oppression remedy in section 163 of the Companies Act for relief if his or her removal from office was oppressive or unfairly prejudicial. Section 163 may also be relied upon by a director removed from office if the removal unfairly disregarded his or her interests - such as a legitimate expectation that he or she would participate in the management of the company or a quasi-partnership. Consequently, if the board removes a director from office in breach of its fiduciary duties or with an ulterior motive, the director concerned may rely on the oppression remedy for relief against the board of directors. He or she would, however, bear the onus of proving that such removal was oppressive, unfairly prejudicial or unfairly disregarded his or her interests; vague or general allegations to this effect would not suffice.

On considering such an application, a court may make any interim or final order it considers fit. It was argued that one such order could be one ordering compensation to be paid to the aggrieved director, subject to section 71(9) of the Companies Act. Further potential orders include a reinstatement order, if appropriate in the circumstances, and an order declaring the impugned directors delinquent or under probation. It was argued that, under the current wording of section 163(1) of the Companies Act, an order restraining the board of directors from passing a board resolution to remove him or her from office, even if such resolution would

${ }^{71}$ S 234(c) of the Australian Corporations Act. 
constitute oppressive or unfairly prejudicial conduct or would unfairly disregard the director's interests, would fall outside the scope of section 163 of the Companies Act.

Since section 163(1) of the Companies Act confers standing on a "director" to apply for relief and not a "former director", it is not clear whether a director removed from office by the board or the Companies Tribunal would in fact have legal standing to institute an application for relief under section 163 of the Companies Act. It is suggested that, in the interests of fairness, clarity and certainty, section 163 of the Companies Act should be amended to state that the provision may be relied upon by a person who has been removed from office by the board of directors (under section 71(3) of the Companies Act) or the Companies Tribunal (under section 71(8) of the Companies Act) if the application relates to the circumstances in which he or she was removed from office. It is consequently recommended that a new section 163(4) of the Companies Act should be inserted, as follows:

“(4) This section shall apply to a person who has been removed from office as a director under section 71(3) or section 71(8) of this Act if the application relates to the circumstances in which the applicant was removed as a director."

It is submitted that such an amendment would remove any doubt that former directors who have been removed from office by the board of directors or the Companies Tribunal in a manner that was oppressive, unfairly prejudicial or that unfairly disregarded their interests, are entitled to apply to court for relief under section 163 of the Companies Act. 